\title{
A material turn in International Relations: the $4 \times 4$, intervention and resistance
}

\author{
Roger Mac Ginty* \\ Professor of Peace and Conflict Studies, University of Manchester
}

\begin{abstract}
This article explores how analysis of material objects offers insights into international intervention and reactions to that intervention. Building on studies that examine the $4 \times 4$ as emblematic of intervention, the article argues that the $4 \times 4$ can also be seen as an object of resistance and agency. To do so, it uses the case study of $4 \times 4$ usage in Darfur and draws on primary data including interviews and a UN security incident database. The article is mindful of the limitations of a 'material turn' in the study of International Relations, especially in relation to how it might encourage us to overlook agency and structural power. While finding new materialism arguments largely convincing, the case study encourages a note of caution and proposes the notion of 'materialism+', which allows for the further investigation of the human/non-human interface, but is circumspect about tendencies towards neophilia, dematerialism, and posthumanism.
\end{abstract}

\section{Keywords}

Objects; New Materialism; Agency; Intervention; Resistance; Darfur

\section{Introduction}

At around 11:00 hrs on 11 June 2008, one (1) Land Rover pickup vehicle rented by [name of INGO removed] was carjacked by unknown armed bandits at water point inside the IDPs Camp in Shangil Tobay. The INGO national staff member, who was driving the car, is missing. - UN report on carjacking in Darfur, 2008.

This article seeks to extend analyses of international intervention, and local and national responses to that intervention, by drawing on the 'material turn' that has been explored by some authors in International Relations (IR) and more substantially by authors beyond IR. It examines how a seemingly inanimate object - the $4 \times 4$ vehicle (often called a land cruiser or sports utility vehicle) - offers an analytical entry point into the extended political economies of contemporary conflict, and humanitarian and security responses to those conflicts. Much recent literature has used the $4 \times 4$ to illustrate the securitised, privileged, and possibly colonialist nature of international intervention. ${ }^{1}$ This article seeks to go further and discusses the use of $4 \times 4$ s by local and national actors too. In other

* Correspondence to: Roger Mac Ginty, HCRI, Ellen Wilkinson Building, University of Manchester, Manchester, M13 9PL. Author's email: roger.macginty@manchester.ac.uk

${ }^{1}$ Mark Duffield, 'From immersion to simulation: Remote methodologies and the decline of area studies', Review of African Political Economy, 41:sup1 (2014), pp. S75-94, 85. See also Séverine Autesserre, Peaceland: Conflict Resolution and the Everyday Politics of International Intervention (Cambridge: Cambridge University 
words, the $4 \times 4$ is not simply a vehicle (pun intended) of intervention. It is also an object of resistance, mimicry, production, consumption, and war-making.

The principal aim of the article is to show how material objects and the 'social life of things' constitutes a useful analytical vantage point from which to observe the complex interactions that make up contemporary conflict and intervention. The article is sympathetic to new materialism arguments that attempt to move beyond the inanimate/animate or non-human/human divide. ${ }^{3}$ The interstices, hybridities, and assemblages comprised of the complex interactions between humans and non-human objects are indeed important, but it is also crucial to recognise the vibrancy of matter or that things have power and energy in themselves independent of interpretations and representations imposed by humans. ${ }^{4}$ The case study, however, encourages some caution with regard to the new materialism arguments. The notion of materialism + is put forward as an indication of the need to move beyond simple materialism but also to signal that circumspection is required before a full acceptance of all that new materialism entails.

In service of the central aim of showing how material objects provide a useful methodological and analytical vantage point for the study of intervention, the article has three objectives. Firstly, and enabled by a case study of $4 \times 4$ usage, it aims to put forward the notion of materialism+. This is a compromise position between materialism and new materialism. While new materialism arguments are largely convincing, especially in relation to the need to move beyond the material/non-material divide, the case study at the heart of this article demands caution. The article's second objective is to make the case that the $4 \times 4$ should be seen as a vehicle of agency, resistance, mimicry, and hybridity in addition to the cliche of the white land cruiser as an object of intervention. This argument is reinforced by the observation that $4 \times 4$ s constitute lifeworlds and are specific to the ontology of specific actors. The final objective has a methodological ambition in using the $4 \times 4$ as a conflict analysis tool to explain the character of contemporary conflict and intervention. Conflict analysts suffer from a 'crisis of access' conflict sites, yet by focusing on multiple small data points (in this case the usage of $4 \times 4 s$ in Darfur), it is possible to build a picture of contemporary violent conflict, particularly the long chains of implication that go from manufacturer in the global north to violent or humanitarian actor in the global south.

In terms of structure, the article begins with a brief note on methodology. The second section makes the case for materialism as a lens with which to analyse conflict, intervention, and resistance.

Press 2014); and Lisa Smirl, Spaces of Aid: How Cars, Compounds and Hotels Shape Humanitarianism (London: Zed Books, 2015).

2 Arjun Appadurai, The Social Life of Things: Commodities in Cultural Perspective (Cambridge: Cambridge University Press, 2013), p. 3.

${ }^{3}$ Important contributions to this new materalisms literature include Diana Coole and Samantha Frost, 'Introducing the new materialisms', in Diana Coole and Samantha Frost (eds), New Materialisms: Ontology, Agency and Politics (Durham and London: Duke University Press, 2010), pp. 1-46; Martin Coward, 'Between us in the city: Materiality, subjectivity, and community in the era of global urbanization', Environment and Planning D: Society and Space, 30:3 (2012), pp. 468-81; Martin Coward, Urbicide: The Politics of Urban Destruction (London and New York: Routledge, 2009); Tom Lundberg and Nick Vaughan-Williams, 'New materialism, discourse analysis and international relations: a radical intertextual approach', Review of International Studies, 41:1 (2015), pp. 3-25.

${ }^{4}$ Jane Bennett, Vibrant Matter: A Political Ecology of Things (Durham and London: Duke University Press, 2010)

${ }^{5}$ Roger Mac Ginty and Oliver Richmond, 'The fallacy of constructing hybrid political orders: a reappraisal of the hybrid turn in peacebuilding', International Peacekeeping, 23:2 (2016), pp. 219-39 (p. 232). 
This section is influenced by the new materialisms literature, but is unable to share fully all of the enthusiasms found in new materialism theory. The article puts forward the notion of materialism+, a position that embraces the disruptive capability of new materialism but is cautious of the tendencies towards neophilia, dematerialisation, and posthumanism found in some debate on new materialism. In its third section, the article shows how the $4 \times 4$ vehicle illustrates bottom-up agency as well as the top-down interventions it is more usually associated with. On the one hand, the $4 \times 4$ is a device of international intervention and offers international actors material and symbolic power with which to promote agendas of humanitarianism, stabilisation, and possibly neocolonialism. Yet, on the other hand, local and national actors utilise $4 \mathrm{x} 4 \mathrm{~s}$ and they are integral to strategies and tactics of resistance, mimicry, extraction, and power projection. Importantly, in this case, the material object is not just an object of consumption. It becomes an object of production as it is used and reused to generate rent and symbolic capital. The fourth section, drawing directly on a UN security incident dataset, examines how multiple data points on a seemingly obscure aspect of conflict can, in fact, provide useful tools for conflict analysis. The conclusion returns to the utility of a material turn in IR and discusses concerns that such an approach might hasten a move to posthumanism, or the downgrading of people and agency from analyses.

It is important to note that the starting point of this article is empirical observation and fieldwork. This sets it apart from many (but no means all) studies of new materialism and may account for its cautiousness with regard to some of the directions new materialism research has taken.

\section{A note on methodology}

While much of this article takes the form of conceptual scoping, it also has an empirical basis. The article arose from an ESRC-funded secondary data analysis project that gave the author access to an African Union-United Nations Joint Mission Analysis Centre (JMAC) security incident dataset from the conflict in Darfur. ${ }^{6}$ The security incident dataset was compiled in real-time and comprises of a spreadsheet of 5,000+ incidents (like the one at the beginning of the article) sent from UN peacekeepers in the field to JMAC. The dataset covers incidents between 3 January 2008 and 6 April 2009, or the first 15 months of the UNAMID (United Nations Mission in Darfur) deployment. Before use it was anonymised and has been used in accordance with data protection provisions. The scale of $4 \times 4$ usage and theft in the Darfur conflict was not clear to the author until viewing the dataset. This prompted a more granular manual search of the database and, following coding, computerised searches. The apparent frequency of vehicle theft also prompted the author to hold semi-structured interviews to gain more contextual information. Interviews were conducted with 17 former and current UN and INGO personnel in Khartoum (March 2014), New York (May 2015), the UK (June 2016), and via Skype (2014-17). Initial interviewees were identified through the author's professional network and thereafter via snowballing. All interviews were conducted on the basis of anonymity for interviewees, and a number of interviewees asked for 'off the record' interviews - hence the absence of direct quotations in some cases. The author did not travel to Darfur. The research was conducted with ethical approval from the University of Manchester.

${ }^{6}$ ESRC project ES/L007479/1, 'Making Peacekeeping Data Work for the International Community'. Further information on the role of JMACs can be found in Philip Shetler-Jones, 'Intelligence in integrated UN peacekeeping missions: the Joint Mission Analysis Centre', International Peacekeeping, 15:4 (2008), pp. 517-27 and Melaine Ramjoué, 'Improving UN intelligence through civil-military collaboration: Lessons from the Joint Mission Analysis Centres', International Peacekeeping, 18:4 (2011), pp. 468-84. 
The article uses Darfur, a site of extensive $4 \times 4$ use, as its principal case study. While the focus is on Darfur, it is hoped many of the insights from that context may be more generally applicable to other sites of conflict and international intervention. There is no claim that Darfur is representative of other cases, merely indicative.

\section{The material turn}

Recent years have seen local, ${ }^{7}$ narrative, ${ }^{8}$ everyday, ${ }^{9}$ sociological, ${ }^{10}$ and anthropological ${ }^{11}$ 'turns' as scholars have sought to unpack the liberal peace. This article invokes socio-materiality or the extent to which objects signify relationships and cosmologies. Daniel Miller's observation that, 'objects create subjects much more than the other way around"12 is challenging in that it forces us to think of limits to individual and collective agency. Yet agency, and especially the ability of local actors to exercise their will in the face of international intervention, has been a major focus of much IR scholarship in recent years. ${ }^{13}$ This article seeks to contribute to the debate on the dynamic relationship between agency and objects, and hopes to move beyond the view that inanimate objects are only enlivened through context and constructionism. Certainly the meanings of materiality are often mediated through human interaction that renders an object into a symbol or device for production, consumption, compliance, or resistance. A large part of this article rests on insights from the representation and political meanings given to inanimate objects and so before discussing the new materialism lens, it is important to entertain materialism and the use of material objects as part of an evidential trail in the study of social phenomena.

Interpreting IR through material objects is in keeping with a number of other research directions in the discipline such as recent studies of spaces and the possibilities of new (nano, digital, neuroscientific, etc.) technologies. Literature on spaces (a form of matter) has focused on sovereignty, borders, new mobilities and the need to think of post-territorial conceptualisations of space. ${ }^{14}$

${ }^{7}$ Hanna Leonardsson and Gustav Rudd, 'The "local turn" in peacebuilding: a literature review of effective and emancipatory peacebuilding', Third World Quarterly, 36:5 (2015), pp. 825-39.

${ }^{8}$ Richard Jackson and Gareth Hall, 'Talking about terrorism: a study of vernacular discourse', Politics, $36: 3$ (2016), pp. 292-307.

${ }^{9}$ Stephen C. Roach, 'Affective values in International Relations: Theorizing emotional actions and the value of resilience', Politics, 36:4 (2016), pp. 400-12; Matthew Donoghue, “"Common senses”: Everyday narratives of community and cohesion in New Labour's Britain', Politics, 36:3 (2016), pp. 262-76; Oliver P. Richmond and Audra Mitchell (eds), Hybrid Forms of Peace: From Everyday Agency to Post-Liberalism (Basingstoke: Palgrave, 2011).

${ }^{10}$ John D. Brewer, Peace Processes: A Sociological Approach (Cambridge: Polity, 2010).

${ }^{11}$ Gearoid Millar, An Ethnographic Approach to Peacebuilding: Understanding Local Experiences in Transitional States (Abingdon: Routledge, 2014).

${ }^{12}$ Daniel Miller, The Comfort of Things (Cambridge: Polity, 2008), p. 298.

${ }^{13}$ Stefanie Kappler, Local Agency and Peacebuilding: European Union and International Engagement in Bosnia Herzegovina, Cyprus and South Africa (Basingstoke: Palgrave, 2014); David Chandler, 'Peacebuilding and the politics of non-linearity: Rethinking "hidden" agency and "resistance"', Peacebuilding, 1:1 (2013), pp. 17-32.

${ }^{14}$ John Williams, 'Space, scale and Just War: Meeting the challenge of humanitarian intervention and transnational terrorism', Review of International Studies, $34: 4$ (2008), pp. 581-600; Nick Vaughan-Williams, 'The generalized bio-political border? Reconceptualising the limits of sovereign power', Review of International Studies, 35:4 (2009), pp. 729-49; Debbie Lisle, Holidays in the Danger Zone: Entanglements of War and Tourism (Minneapolis: University of Minnesota Press, 2016); Annika Björkdahl and Susanne Buckley-Zistel (eds), Spatialising Peace and Conflict: Mapping the Production of Place, Sites and Scales of Violences (Basingstoke; New York: Palgrave Macmillan, 2016). 
Importantly, a number of works have conceived of space as ontological - lifeworlds constituted by enactment. ${ }^{15}$ Work on the possibilities of digital technologies has examined issues of regulation, ethics, and biopolitical challenges. ${ }^{16}$ Echoing the new materialism literature (to be discussed later) literatures on space and technology concur on the need to see their subjects as more than matter these dimensions and items are constituted by humans, but - in turn - constitute humans through complex processes of interactionism.

One motivation for using material objects to understand the political economies of violent conflict and intervention is that many of the actors involved in these processes are less than transparent. Many international organisations, INGOs and state militaries produce significant amounts of publicly available material, and their personnel often consent to be interviewed. Yet there may be discrepancies between the official account of action, and actions actually taken. In the case of rebel and militia groups, safe access for the researcher can be problematic, ${ }^{17}$ although work on rebel governance and the anthropology of rebellion points to some very brave researchers. ${ }^{18}$ The lack of transparency encourages us to explore other evidential trails that may depict the nature of conflict and intervention. A focus on material objects allows us to examine the processes of objectification whereby objects are made and remade through use, language, and circulation. ${ }^{19}$ This social construction will be moulded by context, with the same object acquiring different properties according to time and space. As Neil MacGregor noted in his A History of the World in 100 Objects, 'The object becomes a document not just of the world for which it was made, but for the later periods which altered it. ${ }^{20}$ Crucially, these material palimpsests can be used for purposes other than those originally intended by the manufacturer or regulator. ${ }^{21}$ Usage tells a story that may help us access the 'hidden transcript ${ }^{22}$ of a society - stories of resistance, mimicry, and polymorphism. Manufacturers, advertisers, pressure groups and governments may seek to impose approved usages on objects, for example branding some as 'humanitarian goods', ${ }^{23}$ but 'systems use' (how an object is actually used) and 'normative use' (its recommended use) may differ considerably. ${ }^{24}$ As will be

15 Autesserre, Peaceland and Smirl, Spaces of Aid. See also 'Special Section: Objects and spaces of intervention: Honouring the work of Lisa Smirl (1975-2013)', Journal of Intervention and Statebuilding, 10:1 (2016); Francois Audet, 'Humanitarian space', in Roger Mac Ginty and Jenny H. Peterson (eds), The Routledge Companion to Humanitarian Action (Abingdon: Routledge, 2015), pp. 141-52.

${ }^{16}$ See, for example, Caroline Kennedy and James I. Rogers, 'Virtuous drones?', International Journal of Human Rights, 19:2 (2015), pp. 211-27; Lauren Wilcox, 'Drone warfare and the making of bodies out of place', Critical Studies of Security, 3:1 (2015), pp. 127-31; Peter Newell, 'Democratising biotechnology? Deliberation, participation and social regulation in a neo-liberal world', Review of International Studies, 36:2 (2010), pp. 471-91; and Daniel McCarthy, Power, Information Technology, and International Relations Theory: The Power and Politics of US Foreign Policy and the Internet (Basingstoke: Palgrave, 2015).

17 Sybert Liebenberg, Richard Haines, and Geoff Harris, 'A theory of war economies', African Security Review, 24:3 (2015), pp. 307-23 (p. 308).

${ }^{18}$ See, for example, work by Autessere, Peaceland; Carolyn Nordstrom, Shadows of War: Violence, Power and International Profiteering in the Twenty-First Century (Berkeley: University of California Press, 2004); Romain Malejacq and Dipali Mukhopadhyay, 'Yes it's possible to do research in conflict zones: This is how', Washington Post (5 April 2017).

19 Shakini Shankar, 'Metaconsumptive practices and the circulation of objectifications', Journal of Material Culture, 11:3 (2006), pp. 293-317 (p. 294).

${ }^{20}$ Neil MacGregor, A History of the World in 100 Objects (London: Penguin Books, 2012), p. xxi.

${ }^{21}$ Paul Graves-Brown, 'Avtomat Kalashnikova', Journal of Material Culture, 12:3 (2007), pp. 285-307 (p. 286).

22 James C. Scott, Domination and the Arts of Domination (New Haven, CT: Yale University Press, 1990).

${ }^{23}$ Jamie Cross, 'The 100th object: Solar lighting technology and humanitarian goods', Journal of Material Culture, 18:4 (2013), pp. 367-87.

${ }^{24}$ Shankar, 'Metaconsumptive practices and the circulation of objectifications'. 
discussed later, this is the case with $4 \times 4$ s that can have multiple buyers, sellers and owners during a long life history, and can be modified in numerous ways. As an enthusiast website noted with respect to the Toyota Land Cruiser: popular with 'tradies and the Taliban'. ${ }^{25}$

Ian Walters observes that 'the very physicality of the object, which makes it appear so immediate, assimilable, sensual, belies its actual character'. ${ }^{26}$ The everyday-ness of an object may be accentuated by its ubiquity, accessibility, and mundane nature. Mass-produced items will contain the same parts or ingredients and may have universal branding. Coca-Cola and Apple, and many other products and corporate brands, constitute forces of isomorphism that suggest common experiences and even the achievement of shared standards of modernity. Yet, of course, artefacts are inflected with social meaning through their usage, modification, culture, economics, and politics. ${ }^{27}$ The $4 x 4$, depending on type and the socioeconomic value given to it, can be a luxury object of desire, but it can also be an utilitarian object required for strictly functional purposes: covering rough terrain, pulling heavy loads, carrying troops and looted goods. On the one hand, the $4 \times 4$ has achieved an iconic place in many societies in the global north. It has variously been seen as emblematic of excess, emasculation, ${ }^{28}$ and the securitisation of everyday life. ${ }^{29}$ Josh Lauer noted how such so-called Chelsea tractors or soccer mom vans "lent "yuppies" and wealthy suburbanites an aura of roughness that few could legitimately claim, ${ }^{30}$ On the other hand, the use of $4 \times 4$ s by apparently incorrigible militants groups such as Islamic State and the Taliban prompted a round of media securitisation of the $4 \times 4$. A former US Ambassador to the UN noted that 'Regrettably, the Toyota Land Cruiser and Hilux have effectively become almost part of the ISIS brand. ${ }^{31}$

Anthropological and sociological lenses allow us to see the extra-economic dimensions of material objects and their users. A strict economic view may encourage the rendering of an object into an economic value. ${ }^{32}$ By going beyond economic value we are confronted with a world of motivations, gifting, inheritance, borrowing, hoarding, and storage whereby the object has affective and life-shaping dimensions. In effect, the inanimate and the affective meet, with the former being given forms of life by the latter.

The new materialism literature encourages us to examine the 'mutual constitution of humansnonhumans ${ }^{33}$ and 'technologies in intimate integration with humans'. ${ }^{34}$ While matter matters, it is

${ }^{25} 4 \times 4$ Australia, 'The 10 Greatest $4 \times 4$ s of All Time', 4x4 Australia (7 October 2015), available at: \{http:/l www.4x4australia.com.au/drive/1510/the-10-greatest-4x4s-of-all-time/\}.

${ }^{26}$ Ian Walters, 'Vietnam Zippos', Journal of Material Culture, 2:1 (1997), pp. 61-75 (p. 63).

${ }^{27}$ Aafke Komter, 'Heirlooms, Nikes and bribes: Towards a sociology of things', Sociology, 35:1 (2001), pp. 59-75 (p. 60).

${ }^{28}$ Mary Beckman, 'How to sell Humvees to men', Science (4 August 2005), available at: \{http://www.sciencemag. org/news/2005/08/how-sell-humvees-men\} last accessed 16 May 2016.

${ }^{29}$ David Campbell, 'The biopolitics of security: Oil, empire and the sports utility vehicle', American Quarterly, 57:3 (2005), pp. 943-72.

${ }^{30}$ Josh Lauer, 'Driven to extremes: Fear of crime and the rise of the sport utility vehicle in the United States', Crime, Media, Culture, 1:2 (2005), pp. 149-68.

${ }^{31}$ Samuel Osborne, 'Why does ISIS have so many Toyota trucks', Independent (7 October 2015), available at: \{http://www.independent.co.uk/news/world/middle-east/why-does-isis-have-so-many-toyota-trucks-a6684336. html\} last accessed 16 May 2016.

${ }^{32}$ James Ferguson, 'Cultural exchange: New developments in the anthropology of commodities', Cultural Anthropology, 3:4 (1988), pp. 488-513.

${ }^{33}$ Vicki Squire, 'Desert "trash": Posthumanism, border struggles, and humanitarian struggles', Political Geography, 39 (2014), pp. 11-21 (p. 18).

${ }^{34}$ Charles Hables Gray, 'Post human soldiers in postmodern war', Body and Society, 9:4 (2003), pp. 215-26 (p. 218). 
more than just matter and we are encouraged to think of "the emergent or generative powers of "matter" and the complex yet intertwined formation of "objects", "bodies", and "subjectivities" that this entails. ${ }^{35}$ The social construction of objects is not to be under-estimated, ${ }^{36}$ yet to leave our analysis at this point risks missing the ontological and normative aspects of products and how they intersect with belief systems. ${ }^{37}$ As Vicki Squire notes pithily, we may become stuck on 'object fetishism, ${ }^{38}$ The new materialisms literature on the vitality of objects and how they are 'more than human ${ }^{39}$ encourages at least two lines of thinking in relation to $4 \times 4 s$ in Darfur. Firstly, the $4 \times 4$ embodies and becomes the professional and the personal, even intimate, lifeworlds of those who use them. The professional aspect is well known with the cliché of the humanitarian $4 \times 4$ sweeping through the village scattering villagers in a dust cloud. Driving in, or being driven in, a $4 \times 4$ may also be seen as a 'badge of honour' by some. One academic acquaintance recalls how a human rights activist in Colombia, contracted by the US government, 'was very pleased that she could give us a ride back from the village to the municipality in her car' ${ }^{40}$ But the personal aspect of the $4 \times 4$ is less well explored. The interior of the vehicle constitutes a micro-cosmos. ${ }^{41}$ For one UN employee involved in humanitarian convoys in Syria, the $4 \times 4$ became home for days on end as access was being negotiated to besieged enclaves. ${ }^{42}$ One female British Government employee noted how the interior of armoured vehicles, with their non-opening windows, can be oppressive: 'if someone farts you're fucked'. ${ }^{43}$ The seating arrangements are dictated by status and gender. Mission leaders usually sit in the front passenger seat, but according to one interviewee 'statistically, the seat behind the driver is the safest'. ${ }^{44}$ In many missions, national staff are the drivers and expatriate staff are the passengers - leading to a racialised division of labour. No interviewee could ever remember seeing a female drive a vehicle in Darfur. ${ }^{45}$ The key point is that, in certain circumstances, people are constituted by things. ${ }^{46}$ It is not simply that the $4 \times 4$ (and other objects) represent status, identity, and purpose as a rebel, militia member, UN peacekeeper, or humanitarian worker. Material objects are constitutive of these identities and bring with them affective reactions from both those inside and outside the $4 \times 4$. By creating (and recreating) lifeworlds, the material dimension strays into ontology whereby existence and purpose are due, to a significant degree, to the possession and utilisation of material objects. To put it bluntly, it is difficult to imagine an active rebel or militia member operating in Darfur without a $4 \times 4$.

The $4 \times 4$ can also shape epistemology in quite literal ways. The inhabitant may be encased in an armoured vehicle, physically insulated from the territory and people they are - notionally - working with. A former UN peacekeeper, and a UN human rights monitor (both with experience in Darfur)

35 Vicki Squire, 'Reshaping geopolitics? The materialist challenge', Review of International Studies, 41 (2014), pp. 139-59.

${ }^{36}$ Daniel R. McCarthy, 'The meaning of materiality: Reconsidering the materialism of Gramscian IR', Review of International Studies, 37:3 (2010), pp. 1215-34 (p. 1216).

37 Ibid., p. 1223.

38 Squire, 'Reshaping geopolitics?', p. 149.

39 Ibid., p. 148.

40 The author is grateful to Pamina Firchow for this anecdote.

${ }^{41}$ Lorena Rizzo, 'Between the book and the lamp - interiors of bureaucracy and the materiality of colonial power', African Historical Review, 45:2 (2013), pp. 31-51.

42 Author interview with UN human rights monitor, 8 March 2017.

${ }^{43}$ Interview with British Government employee, 1 June 2016.

44 Ibid.

${ }^{45}$ It is legal for women to drive in Sudan.

${ }^{46}$ Miller, The Comfort of Things. 
confirmed that the UN could only record what its personnel could witness and that this view was often limited by the $4 \times 4 .{ }^{47}$ For example, the $4 \times 4$ might be physically limited in where it can go, the movement control officer might declare certain routes off-limits, or the Sudanese authorities may thwart $4 \times 4$ journeys. So the $4 \times 4$ facilitates and limits standpoint epistemology and situated knowledge. ${ }^{48}$

A second point that emerges from the new materialism perspective is that objects are part of interlocking systems. ${ }^{49}$ This point has been well made by Marxists and Gramscians who have pointed to the relationships between technology, belief systems, power, and behaviour. ${ }^{50}$ Complex political economies mean that a $4 \times 4$ might be purchased and ordered by an INGO headquartered in the Netherlands, built in a factory in Japan, kitted out in Gibraltar, shipped to Port Sudan, convoyed to Darfur, used by personnel working on an infant mortality project, be carjacked in Darfur, and be used by a rebel commander before being sold in Chad. During this 'journey', the vehicle might variously be the object of a commercial transaction, comfort, fear, and employment (for carmakers and drivers). Some material objects, in this case the $4 \times 4$, constitute a chain of implication linking apparently remote conflict locations to everyday activity in the global north. Scholars from IR and other disciplines have been useful in highlighting how violent conflict is often othered and exoticised as something that happens 'over there'. ${ }^{51}$ By tracking the material objects of conflict it is possible to question this othering and instead point to a chain of implication that unites the rebel, militia fighter, or humanitarian in the $4 \times 4$ with the $4 \times 4$ on many driveways in the global north. So keen are manufacturers to trumpet the security and all-terrain advantages of their wares that they invoke their military and humanitarian usages in advertising. Toyota Europe, for example, quotes from a Médecins Sans Frontières (MSF) logistician who describes the Land Cruiser as 'truly unbreakable'. ${ }^{52}$ A minor media storm erupted when a Texas plumber saw his former pick-up truck being used by Islamic State in Syria. ${ }^{53}$ This long chain of implication relies on shared meanings of the $4 \times 4$ that go beyond its undoubted physical usefulness. Thus, and in keeping the new materialism perspective, political economies are augmented by moral economies that have an affective dimension.

While this article appreciates the disruptive and original direction of the new materialism thesis, the case study basis of the article urges caution. This circumspection encourages the author to put

${ }^{47}$ Author interviews, 9 November 2016.

${ }^{48}$ Marysia Zalewski, 'Feminist standpoint theory meets International Relations theory: a feminist vision of David and Goliath', Fletcher Forum of World Affairs, 17:2 (1993), pp. 13-22; Donna Haraway, 'Situated knowledges: the science question in feminism and the privilege of partial perspective', Feminist Studies, 14:3 (1988), p. 594.

${ }^{49}$ See, for example, Mark Rupert, Producing Hegemony: The Politics of Mass Production and American Global Power (Cambridge: Cambridge University Press, 1995).

${ }^{50}$ McCarthy, 'The meaning of materiality', p. 1223.

${ }^{51}$ Richard Jenkins, 'Imagined but not imaginary: Ethnicity and nationalism in the modern world', in Jeremy MacClancy, Exotic No More: Anthropology on the Front Lines (Chicago: University of Chicago Press), pp. 114-28 (p. 115); Hazem Abu-Orf, 'Fear of difference: "Space of risk" and anxiety in violent settings', Planning Theory, 12:2 (2012), pp. 158-76; Giorgia Doná, 'Interconnected modernities, ethnic relations and violence', Current Sociology, 61:2 (2012), pp. 226-43.

52 Toyota Europe, 'MSF Chooses Unstoppable Land Cruiser', Your Toyota blog (13 August 2013), available at: \{http://blog.toyota.eu/your-toyota/medecins-sans-frontiers-chooses-unstoppable-land-cruiser/\} last accessed 16 May 2016. See also, Lisa Smirl, Spaces of Aid, p. 103.

${ }^{53}$ Christine Hauser, 'Texas plumber sues car dealer after his truck ends up on Syria's front lines', New York Times (2015), available at: \{http://www.nytimes.com/2015/12/15/us/texas-plumber-sues-car-dealer-after-histruck-ends-up-on-syrias-front-lines.html?_r=0\} last accessed 16 May 2016. 
forward the notion of materialism+, a notion that appreciates the ability to explore 'matter's capacity to pose questions on its own terms ${ }^{54}$ but stops short of embracing three aspects of new materialism. Materialism + thus may be seen as a staging post on the way to new materialism, one necessitated by three unconvincing aspects of new materialism thesis in respect of observations from the case study.

The first point of caution relates to the neophilia much observed in new materialism arguments. To be clear, studies of new materialism are not exclusively restricted to new objects or technologies. Yet there can be no doubting that such a bias can be found in the literature. Tom Roberts observed that 'the emergence of a new materialism within the social sciences is contemporaneous to the mutation of scientific technologies and biotechnologies over the course of the $20^{\text {th }}$ century. ${ }^{55}$ Much of the new materialism literature concentrates on cutting-edge nano, digital, wearable, and biotechnologies. The emphasis on techno-scientific advances stands in contrast to the $4 \times 4$. The technology involved in most $4 \times 4$ use is decidedly intermediate rather than advanced or hyper-advanced. As one UN interviewee said of the Toyota Land Cruiser 'simple mechanics, lots of spare parts'. ${ }^{56}$ Despite the changes in digitally-enabled humanitarianism and the trend towards remote and new public management, a constant factor seems to be the diesel engine and the $4 \times 4 .{ }^{57}$ Indeed, it is worth noting that the UN and some INGOs are frustrated with the increasing sophistication of $4 \times 4 s$ - especially their reliance on advanced electronics. These organisations value the ability to service vehicles in the field and cannabalise older vehicles for spare parts, and so find increasingly sophisticated vehicles a hindrance.

A second note of caution relates to a tendency towards dematerialisation in some of the new materialism literature ${ }^{58}$ It is not the case, of course, that all new materialism literature has a dematerialised focus. ${ }^{59}$ Yet the metaphysical direction of some discussion seems very far removed from the immediate and onsite nature of much contemporary conflict and humanitarianism. The case study material on which this article is based suggests that the demise of traditional forms of intervention using boots on the ground, or tyres on mud roads, can be overstated. In 2016, one humanitarian agency, MSF, had a fleet of 700 Toyota Land Cruisers. Such vehicles are the day-today workhorses of humanitarianism, stabilisation, and peacemaking. The United Nations High Commissioner for Refugees has well over 10,000 vehicles. ${ }^{60}$ Such large numbers point to an onsite materiality of intervention that involves human-to-human contact and all of the complexity and power relations that such interaction involves. Without the $4 \times 4$, the 'aid archipelago' of fortified aid compounds could not exist. ${ }^{61}$ Moreover, the vehicles are composed of raw materials extracted from specific sites in real-time, with consequences in terms of environmental degradation, consumption, and the dislocation of traditional industries. ${ }^{62}$

54 Tom Roberts, 'From “new materialism” to "machinic asemblage”, Environment and Planning, A:44 (2012), pp. 2512-29 (p. 2512).

55 Ibid., p. 2515.

${ }^{56}$ Interview with UN employee, UN Headquarters, New York, 23 May 2016.

57 The author is grateful to Charles Hunt for this point.

${ }^{58}$ A point made by Paul Ciccantell and David A. Smith, 'Rethinking global commodity chains: Integrating extraction, transport, and manufacturing', International Journal of Comparative Sociology, 50:3-4 (2009), pp. 361-84 (p. 365).

59 See, for example, work by Squire on desert 'trash'.

${ }^{60}$ Interview with UN employee, UN Headquarters, New York, 23 May 2016.

${ }^{61}$ Mark Duffield, 'Risk-management and the fortified aid compound: Everyday life in post-interventionary society', Journal of Intervention and Statebuilding, 4:4 (2010), pp. 453-74 (p. 470). See also, Autesserre, Peaceland.

${ }^{62}$ Ciccantell and Smith, 'Rethinking global commodity chains', p. 366. 
A recognition of the grounded and onsite nature of contemporary conflict and humanitarianism is not to deny trends towards remote management in humanitarianism whereby digital technologies allow headquarters to direct more closely ground operations and to liaise directly with national actors (bypassing field offices). ${ }^{63}$ Digital and remote sensing technologies, we are told, offer the potential for postmodern humanitarianism, whereby intervention (and more particularly the management of intervention) occurs remotely and thus possibly reinforces the othering of the subject of intervention. ${ }^{64}$

The trend towards remote management is not in question; yet, the immediate and human costs of onsite physical intervention, humanitarianism, and resistance are evidenced by the killings of significant numbers of humanitarian medical personnel in recent years. ${ }^{65}$

A third point of caution in relation to new materialism is its potential to move towards posthumanism, or situations in which human agency is displaced in narratives and analyses. None of this is to deny the imperative of 'more than human' perspectives and the need to recalibrate how and where humans fit into explanations of conflict. As Erika Cudworth and Stephen Hobden note, new materialism risks overlooking 'the unique specificity of human agency and the transformatory capabilities of our species' ${ }^{66}$ The caution concerned with the posthuman implications of new materialism relates to the normative project at the heart of humanitarianism and critical approaches to peace and conflict studies. As the term suggests, humanitarianism is human centred and often focused on basic and immediate needs. Thus moves towards extreme versions of posthumanism ${ }^{67}$ risk overlooking the essential imperative of remaining focused on human things. In terms of critical approaches to peace and conflict studies, a clear normative intellectual project is underway whereby scholars and scholar-practitioners see their role as part of emancipatory efforts that seek to write people and agency back into analyses of peace and conflict. While posthumanism has been a useful intellectual device (a point revisited in the conclusion) it does demand caution lest it contradicts the normative (and indeed practical) ambitions of humanitarianism, and to a lesser extent critical peace and conflict studies. As the next section hopes to show, multiple forms of agency - many of them complex, subtle and hard to observe - lie at the heart of conflict and responses to conflict. As a result, a lurch too far towards posthumanism seems to move us away from grounded observations.

The key point of this section has been to reaffirm the material turn and beyond that, new materialism. The case study material, however, demands some caution with regards to some aspects

${ }^{63}$ Roisin Read, Bertrand Taithe, and Roger Mac Ginty, 'Data hubris? Humanitarian information systems and the mirage of technology', Third World Quarterly, 37:8 (2016), pp. 1314-133; Stuart Garman, 'New communications technologies in emergencies', in Mac Ginty and Peterson (eds), Routledge Companion to Humanitarian Action, pp. 440-52; Katja Lindskov Jacobsen, The Politics of Humanitarian Technology: Good Intentions, Unintended Consequences, Insecurity (London: Routledge, 2015).

${ }^{64}$ Integrity Research and Consultancy and Axiom Monitoring and Evaluation, No Longer a Last Resort: A Review of the Remote Planning Landscape (London: UK Aid, 2014); S. Collinson and Mark Duffield, Paradoxes of Presence: Risk Management and Aid Culture in Challenging Environments (London: HPG/ODI, 2013).

65 A good summary of the precarious nature of humanitarianism can be found in the Médecins Sans Frontières statement on their withdrawal from the 2016 World Humanitarian Summit: MSF, 'MSF to pull out of World Humanitarian Summit', MSF Press Release (5 May 2016), available at: \{http://www.msf.org.uk/article/msf-topull-out-of-world-humanitarian-summit\}.

${ }^{66}$ Erika Cudworth and Stephen Hobden, 'Liberation for straw dogs? Old materialism, new materialism and the challenge of an emancipatory posthumanism', Globalizations, 12:1 (2015), pp. 134-48 (p. 135).

${ }^{67}$ It should be noted that most studies take a moderate position. 
of the new materialism perspective. As a result, a materialism + perspective was put forward - one cognisant of much of what new materialism has to offer, especially in investigating the inanimateanimate interstices. This position is, however, circumspect on new materialism's tendencies towards neophilia, dematerialisation, and posthumanism. The next section extends the materialism + argument by examining the $4 \times 4$ as an object of resistance and agency.

\section{The $4 \times 4$ as local agency and resistance}

It is relatively straightforward to portray the $4 \times 4$ as emblematic of top-down intervention - an alien intrusion that is clearly not indigenous to the conflict zone. It is a point of separation between the intervener and the intervened, perhaps inviting a rephrasing of the Belloc quip into, 'We have the $4 \times 4$, and they have not.' Lisa Smirl notes how 'The white sports utility vehicle (SUV) has become a symbol of international humanitarian personnel; in many countries better recognised than the symbol of the blue helmet of UN peacekeepers. ${ }^{68}$ One UNAMID employee referred to the $4 \times 4$ as 'Our way of marking our territory. ${ }^{69}$ A UN interviewee referred to the organisation's 'psychological dependence on the great big white vehicle - the dust cloud scattering children and market traders'. ${ }^{70}$

The $4 \times 4$ is less often portrayed as enabling bottom-up agency and resistance. Before developing this point, two caveats should be made. The first is that we should avoid romanticising bottom-up and local forms of agency and resistance. ${ }^{71}$ In some cases it can be emancipatory and enabling, but it can also be violent, exclusionary, and reinforce patriarchy and other established forms of power. ${ }^{72}$ The second caveat is that the top-down/bottom-up binary is too simplistic for a complex situation like Darfur. Although this section concentrates on bottom-up agency, it does so in the knowledge that terms like 'top-down', 'bottom-up', 'local', and 'international' are too static for dynamic and multilateral contexts. ${ }^{73}$ The terms are used in this article on the understanding that they contain dynamism, are gendered, and are a shorthand for very complex categories. Complicating matters are the multitude of actors involved in Darfur. Rather than a tripartite conflict involving a government, rebels, and representatives of the international community, the conflict involves multiple proxies, divisions, defections, and shifting alliances. Actors can straddle the local-national-international categories. The status of the Government of Sudan defies the neat stratifications and categorisations that comprehensible analysis prefers: it is at once a sovereign national government with international recognition, but also a local actor through its militias and proxies. Crucially, the Government of Sudan can be regarded as a resistance actor (resistance is not the sole privilege of the 'underdog'). The Government is engaged in resistance to the international community and has sought to thwart UNAMID and many other international actors who it regards as interfering in matters internal to Sudan. So in discussing agency and resistance, as illustrated by $4 \times 4$ s, this article will also include the Government of Sudan and its proxies who are resisting the mandate of the international community.

${ }^{68}$ Smirl, Spaces of Aid, p. 101.

${ }^{69}$ Interview with former international UNAMID employee, 10 May 2016.

${ }^{70}$ Interview with UN employee, UN Headquarters, New York, 23 May 2016.

${ }^{71}$ Oliver P. Richmond, 'De-romanticising the local, de-mystifying the international: Hybridity in Timor Leste and the Solomon Islands', The Pacific Review, 24:1 (2011), pp. 115-36.

72 Roger Mac Ginty and Oliver P. Richmond, 'The fallacy of constructing hybrid political orders: a reappraisal of the hybrid turn in peacebuilding', International Peacekeeping, 23:2 (2016), pp. 219-39.

73 The much debated literature on the hybrid peace is useful here. 
These caveats aside, $4 \times 4$ usage indicates agency and resistance by Darfurians against the Sudanese state and their proxies. Crucially, and following the earlier discussion of new materialism, actorness can be conferred by possession, use, and association with material objects. The object defines the subject as agential. A limited number of objects have this power, among them in this case the camel, the $4 \times 4$, and the automatic rifle. In this 'object-oriented ontology', ${ }^{74}$ objects are affiliative and notate particular associations or disassociations. In the case of Darfur, the object is not ambivalent, but affirms or modifies narratives about individual and group identity, role and motive. ${ }^{75}$ For example, INGOs might have local chapters that seek to differentiate themselves from their international colleagues. In eastern Democratic Republic of Congo (though not Darfur to the best of the author's knowledge) it is common for NGO-owned $4 \times 4$ s to be painted vivid colours to differentiate them from the ubiquitous white Land Cruiser and the connotations they carry. ${ }^{76}$

Rather than being populated by 'victims' and 'survivors', and rather than being 'remote' and 'isolated', analysis of $4 \times 4$ usage depicts a Darfur containing active, entrepreneurial, and connected people and groups. Many objects do not tell a simple story of passive consumption. Much commentary on consumption is prone to a moralistic tone, regarding it as profligate or indulgent. Frank Trentmann cautions that 'We cannot simply stamp consumption as inauthentic or frivolous. For former slaves and migrants, things were a great emancipator. A shirt, a hat, a watch and a mirror were tickets to social inclusion and self-respect. ${ }^{77}$ So rather than an end-state (Adam Smith regarded consumption as 'the sole end and purpose of all production'), ${ }^{78}$ consumption can be better seen as a stage in a process that involves possibilities for agency, emotion, fulfillment, and display.

In addition to consumption, objects narrate stories of production, co-production, labour, exploitation, resistance, social advancement, and environmental degradation. Production, in particular, points to agency, and possibly resistance and subversion. As Shari Daya noted, "production" is often more than simply the act of making. ${ }^{79}$ It may involve identity construction and change, social (im)mobility, the carving of new relationships, and the creation or stripping away of autonomy. While $4 \times 4$ s are made in factories in Japan, Germany or elsewhere, they can also be 'produced' through modification in seemingly non-industrialised places like Darfur. As the database that is point of origin of this article shows, many $4 \times 4$ s are stolen from humanitarian INGOs and thereafter modified to suit the purposes of the new owner. They may be re-sprayed to hide the logo of the previous owner, the cab may be cut off to create a pick-up truck, and a machine gun might be fitted onto the back. These are processes of production that call on specialised skills and tools. ${ }^{80}$ They render actors in Darfur as more than caricature-like consumers, the drone-like users of objects constructed in the global north. ${ }^{81}$ Local modification and production challenge the notion of the $4 \times 4$ as a standardised mass production item. ${ }^{82}$

74 Clare Humphries and Aaron C. T. Smith, 'Talking objects: Towards a post-social research framework for exploring object narratives', Organization, 21:4 (2014), pp. 477-94 (p. 479).

75 Lucy Suchman, 'Affiliative objects', Organization, 12:3 (2005), pp. 379-99.

76 The author is indebted to Charles Hunt for this point.

${ }^{77}$ Frank Trentmann, Empire of Things: How We Became Consumers, From the Fifteenth Century to the TwentyFirst (London: Allen Lane), p. 134.

78 Cited in ibid., p. 151.

79 Shari Daya, 'Beyond exploitation/empowerment: Re-imagining Southern producers in commodity stories', Social \& Cultural Geography, 15:7 (2014), pp. 812-33 (p. 814).

${ }^{80}$ Interview with former UNAMID national staff member, 4 May 2016.

81 Daya, 'Beyond exploitation/empowerment', p. 816.

82 Adam Smith, An Inquiry into the Nature and Causes of the Wealth of Nations (Kindle edn, Edinburgh: William Strahan and Thomas Cadell, 1776), ch 1: 'Of the division of labour', no pagination. 
The logic of factory production lies in economies of scale through standardisation and repetition. In Darfur, however, standardised objects are routinely modified for humanitarian, peacekeeping, and military purposes. On the one hand, there are trends towards isomorphism with the spread of the $4 \times 4$ and other mass produced objects, but there are also opportunities for personalisation and modification.

Rebel groups have found ways to fuel their fleets, with the security incident database containing multiple reports of the theft of fuel from UN and commercial trucks. Indeed, UN documents show that the United Nations High Commissioner for Refugees had difficulty gaining adequate fuel supplies for its own fleet for a time in $2007 .{ }^{83}$ The $4 \times 4$ shows agency and resistance in the sense that rebel groups, and the population supporting them, adapted to circumstances. Rough and ready car maintenance shops sprang up in towns and trading posts, and small groups travelled with additional fuel in 40-gallon drums. ${ }^{84}$

The $4 \times 4$ is also useful for illustrating resistance and agency by the Government of Sudan, their militias and proxies. All have exercised considerable resistance and subversion to UNAMID and what they regard as unwarranted intrusion in Sudan's affairs. The most obvious and violent resistance comes from the militias and proxies resourced by the Government of Sudan. Included in this resourcing is the supply of $4 \times 4$ s to the Rapid Support Forces, ${ }^{85}$ a pro-Government militia considered as a reconstituted Janjaweed. ${ }^{86}$ Multiple reports, including prosecution documents from the International Criminal Court, attest to human rights abuses by pro-Government militias who travel in weaponised $4 \mathrm{x} 4 \mathrm{~s} .{ }^{87}$ The Government, which has made clear that it wants the UNAMID mission to end, uses multiple acts of obstruction (often involving $4 x 4$ s) to thwart the UN mission. For example, the Government reportedly delays customs checks on UN vehicles at Port Sudan and links customs clearance with political concessions. ${ }^{88}$ The UN and INGOs are often reliant on the Sudanese police to recover stolen $4 \times 4 s-$ a process that may not be straightforward. As one UN employee asked, 'Are the police in Darfur going to help?'89

A final observation on agency comes from interplay between donors and recipients and how the donation of $4 \times 4 s$ by international organisations and INGOs has become a core part of capacitybuilding. Given the terrain, poor road infrastructure, and the distances to be covered, $4 \times 4 \mathrm{~s}$ are essential, rather than a luxury. It not uncommon for capacity-building programmes to include items such as 'logistic support for ... one all-terrain vehicle for liaison purposes' ${ }^{90}$ The donor-recipient

${ }^{83}$ UNHCR, 'Audit of Operations in Darfur (AR2006-115-03)' (7 February 2007), available at: \{https://wikileaks. org/wiki/Office_of_the_United_Nations_High_Commissioner_for_Refugees:_Audit_of_Operations_in_Darfur_ (AR2006-115-03),_7_Feb_2007\} last accessed 10 August 2007.

${ }^{84}$ Interview with former UNAMID national staff member, 4 May 2016.

${ }^{85}$ Ibid.

86 'Janjaweed in Darfur reconstituted as the Rapid Reaction Force', Sudan Tribune (2 March 2014), available at: \{http://www.sudantribune.com/spip.php?article50134\} last accessed 10 August 2016.

${ }^{87}$ Office of the Prosecutor, 'Nineteenth Report of the Prosecutor of the International Criminal Court to the UN Security Council Pursuit of UNSCR 1593' (2005), available at: [https://www.icc-cpi.int/iccdocs/otp/otp-19thUNSC-Dafur-06-14-Eng.pdf\} last accessed 10 August 2016.

${ }^{88}$ Interview with former international UNAMID employee, 10 May 2016.

${ }^{89}$ Interview with UN employee, UN Headquarters, New York, 23 May 2016.

${ }^{90}$ African Development Fund, 'Republic of Sudan: Capacity-Building for Poverty Reduction and Good Governance - Appraisal Report, Governance, Economic and Financial Management Department' (November 2016), available at: \{http://www.afdb.org/fileadmin/uploads/afdb/Documents/Project-and-Operations/Sudan_-Capacity_Building_for_Poverty_Reduction_and_Good_Governance_-_Appraisal_Report.pdf\} last accessed 10 August 2016. 
relationship is more complex than the simple hand over of goods. It often involves a script of requests and demands from both sides, with all parties having an awareness of the political economies of monitoring and evaluation, the new public management vernacular, and competition from other agencies and potential recipients. ${ }^{91}$ In a classic case of mimicry, or what postcolonialists identify as locals speaking back to colonialists, ${ }^{92}$ one former international UNAMID employee noted how mayors or Government of Sudan appointees would only turn up to meetings in a $4 \times 4$. For them it was mark of status intended to say that they were equal to any UN appointee. ${ }^{93}$

\section{Multiple data points in conflict analysis}

In its third major second the article takes a methodological turn, situating itself in the 'crisis of access' experienced by many researchers in relation to conflict-affected zones. The physical and ethical dangers to the researched and the researcher have been well discussed in the literature. ${ }^{94}$ What is worth highlighting, however, is how conflict actors often endeavour to close off sites of conflict to researchers. ${ }^{95}$ Whether this is through the denial of visas (Sri Lanka in the run up to the 2009 defeat of the LTTE); the invocation of security exclusion zones (southern Lebanon); the physical inaccessibility of the conflict zone (Darfur, Yemen); or the reliance of the researcher on UN, INGO, or government gatekeepers with commensurate accusations of bias; the researcher might struggle to access the zone of the intended research.

Reactions to these problems of access might entail methodological innovation whereby researchers take unconventional approaches to compensate for a lack of access. This might involve using autoethnography, ${ }^{96}$ mobile and smartphone technologies, ${ }^{97}$ the crowdsourcing ${ }^{98}$ and crowdseeding ${ }^{99}$ of data, and mixed mode surveys. ${ }^{100}$ It also involves a recognition that conflict areas are not laboratories and so 'good enough' methodologies may have to suffice ${ }^{101}-$ a position with obvious

${ }^{91}$ The author is grateful to Charles Hunt for this point.

${ }^{92}$ Homi K. Bhabha, The Location of Culture (Abingdon: Routledge, 2004).

${ }^{93}$ Interview with former international UNAMID employee, 10 May 2016.

${ }^{94}$ Millar, An Ethnographic Approach to Peacebuilding; Marie Smyth and Gillian Robinson (eds), Researching Violently Divided Societies: Ethical and Methodological Issues (Tokyo: United Nations University Press, 2003).

95 Torin Monahan and Jill A. Fisher, 'Strategies for obtaining access to secretive or guarded organizations', Journal of Contemporary Ethnography, 44:6 (2015), pp. 709-36.

${ }^{96}$ Morgan Brigg and Roland Bleiker, 'Autoethnographic International Relations: Exploring self as a source of knowledge', Review of International Studies, 36:3 (2010), pp. 779-96.

${ }^{97}$ Brian Dillon, 'Using mobile phones to collect panel data in developing countries', Journal of International Development, 24 (2012), pp. 518-27; Gabriel Demombynes, Paul Gubbins, and Alessandro Romeo, 'Challenges and Opportunities of Mobile Phone-Based Data Collection: Evidence from South Sudan', Policy Research Working Paper (The World Bank Africa Region Poverty Reduction and Economic Management Unit, 2013); Naomi F. Sugie, 'Utilizing smartphones to study disadvantaged and hard-to-reach groups', Sociological Methods and Research (2016), Online first, pp. 1-34.

${ }^{98}$ Maja Bott and Gregor Young, 'The role of crowdsourcing for better governance in international development', Praxis: The Fletcher Journal of Human Security, 23 (2012), pp. 47-70.

${ }^{99}$ Peter Van der Windt and Macartan Humphreys, 'Crowdseeding in eastern Congo using cell phones to collect conflict events data in real time', Journal of Conflict Resolution, 60:4 (2016), pp. 748-81.

${ }^{100}$ Edith De Leeuw and Joop Hox, 'Mixed-mode surveys: When and why', in E. De Leeuw, J. Hox, and D. Dillman, International Handbook of Survey Methodology (New York: Psychology Press, 2008).

${ }^{101}$ Wendy Luttrell, “'Good enough" methods for ethnographic research', Harvard Educational Review, 70:4 (2000), pp. 499-523. 
consequences for the robustness of data and scientific replicability. The current research on $4 \times 4 \mathrm{~s}$ shows how seemingly idiosyncratic avenues of research can be revealing as to the character of violent conflict. The argument advanced here is that the examination of the role of $4 \times 4 \mathrm{~s}$ in the Darfur conflict can act as a conflict analysis device to complement other approaches to analysing violent conflict.

This argument is advanced in the knowledge that conflict analysis frameworks (used primarily by international organisations and INGOs, but also by academics) have been undergoing standardisation. ${ }^{102}$ The advantage of standardisation is comparability - useful for the interoperability of intervening organisations. The disadvantage, however, is that standardised conflict analyses tend to produce the same answers and exclude alternative explanations for conflict onset and maintenance, and for the character of the conflict. By examining $4 \times 4$ usage in the security incident dataset we are presented with multiple data points. In singularity these data points do not tell us very much about the character of the conflict. Cumulatively, however, they offer a narrative of the conflict that may also have analytical worth. Conflict analysis is charged with representing the 'who, what, why and where' of a conflict. An analysis of $4 \times 4$ usage does just that by offering insights into conflict actors, motivations, modus operandi, and resourcing. Put simply, it is difficult to conceive of contemporary patterns of conflict, peacekeeping, and humanitarianism in Darfur in the absence of the $4 \times 4$. The conflict, more correctly described as an interlocking series of conflicts that have been ongoing for decades, mixes high and low technology with high and low intensity warfare. ${ }^{103}$ The conflict causation and maintenance factors include resource competition and degradation, race and identity, the insecurity of the Khartoum regime, the fractured nature of opposition groups, and regional instability. A number of scholars have emphasised the importance of structural and political economy explanations for the conflict. ${ }^{104}$

Harry Verhoeven, Lydiah Kemunto Bosire, and Sharath Srinivasan's description gives a good account of the all-encompassing nature of the violence:

scorched earth tactics in which displacement and terror are often more important than actual killing; the dehumanising discourse that stirs up hate and antagonises communities; the use of proxy militias, composed of groups marginalised in their own right, who are given total impunity to combat the enemy; the systematic transfer of assets (cattle, land, water holes, etc.) from those targeted by the government to those fighting for Khartoum; the aerial bombardment of civilians and the use of aid as a weapon against people; the false cease-fires and the relentless obstruction of humanitarian operations to wear down the international community and rebel opposition. ${ }^{105}$

102 Conflict Sensitivity Consortium, 'Conflict Sensitivity Consortium Benchmarking Paper', Draft (29 April 2009), available at: \{http://local.conflictsensitivity.org/wp-content/uploads/2015/05/CSA-Benchmarkingpaper-full.pdf\}; Jennifer Causton, 'The challenge of mainstreaming conflict sensitivity: PCIA methodologies and the organizational culture of NGOs', ATLIS Journal, 5 (2009), available at: http://atlismta.org/onlinejournals/0809-journal-intervention/\};Gary T. Furlong, The Conflict Resolution Toolbox: Models and Maps for Analysing, Diagnosing and Resolving Conflict (Toronto, ON: Wiley, 2005).

103 Alex De Waale, The Real Politics of the Horn of Africa: Money, War, and the Business of Power (Cambridge: Polity, 2015), pp. 65-6.

104 Stephen P. Reyna, 'The disasters of war in Darfur, 1950-2004', Third World Quarterly, 31:8 (2010), pp. 1297-320.

105 Harry Verhoeven, Lydiah Kemunto Bosire, and Sharath Srinivasan, 'Understanding Sudan's saviors and survivors: Darfur in the crossfire between humanitarian fundamentalism and Khartoum's divide and rule', Review of African Political Economy, 36:122 (2009), pp. 630-5. 
The displacement and dispossession of Darfurians are key aims of the Sudanese government (with an estimated two million people displaced from the 1990s onwards). ${ }^{106}$ The 'actorness' of the conflict defies easy explanation and goes far beyond a simple rebel versus government or African versus Arab binary. The Sudanese government relies heavily on proxy militias some of which are formally aligned with the police and military. They maintain strong, but less formal, links with the Janjaweed - an Arab militia that has been implicated in mass human rights violations. ${ }^{107}$ The rebels coalesce around the Justice and Equality Movement and the Sudanese Liberation Army but are riven with division. ${ }^{108}$

An object that links many actors in the conflict - government, militias, rebels, peacekeepers, INGOs, and even fleeing refugees - is the $4 \times 4$. The extent to which the $4 \times 4$ plays a vital role in the conflict is evidenced by the United Nations Mission to Darfur security incident log. Taking the form of an Excel spreadsheet mentioned in the methodological note near the beginning of this article, it is a list of the date, location, and type of security incidents in the Mission area of operations ranging from bombings and shootings to intimidation and sexual assault. These security incident logs, which are collated on a daily basis, originate in field missions before being passed through the Joint Mission Analysis Centres (JMAC) and thenceforth onto New York. They constitute an official narrative of the security aspects of the mission and are important documents because policy and resourcing decisions may be based on the story they tell. A perusal of the UN security incident $\log$ from Darfur for an eighteen-month period in 2008-9 contains a startling story. Alongside the recording of thousands incidents of ethnic cleansing, abduction, bombing, village burnings, and assaults, there are hundreds of reports of the theft and hijacking of vehicles. Indeed, there are 283 reports of hijacking or attempted hijacking. Seventeen of these incidents involved loss of life, and 165 of the incidents involved vehicles in the service of aid organisations. One aspect of the conflict can be seen as a massive asset transfer from organisations based in the global north to organisations (mainly rebel groups) in the global south. The sheer number of $4 \times 4$ s stolen in a relatively short time period points to a significant injection of resources into a conflict zones, and the local appropriation of these resources. They encourage us to look afresh at the complex political economy of a conflict and observe how local and national agency mixes with transnational flows of resources.

The UN security incident log contains reports such as:

On 11 March, one INGO vehicle along with seven national staffs was hijacked at Sisi (40 km southeast of El Geneina). The INGO staffs were later released.

On 13 March 08 at approximately 12:00 hrs in Kerenek Village (EG locality), an INGO vehicle, Toyota Land Crusier Buffalo, with two (2) staff members on board was stopped and carjacked by three (3) unknown armed bandits, all in military fatigues and armed with AK-47 rifles.

On 25 March 2008 at about 1045 hrs an INGO NCA Buffalo type Vehicle with a driver and passenger was car-jacked in Hassa Hissa IDP camp at the clinic by two (2) persons, one (1) of them armed with an automatic weapon. The two (2) bandits commandeered the vehicle towards North West of the camp. All the GoS Security organs and

${ }^{106}$ Hugo Slim, Killing Civilians: Methods, Madness, and Morality in War (London: Hurst, 2007), p. 106.

107 United Nations, 'International Commission of Inquiry on Darfur: Report to the Secretary General, 25 January 2005' (Geneva: United Nations, 2005), available at: \{http://www.un.org/news/dh/sudan/com_inq_darfur.pdf\}.

${ }^{108}$ Interview with former UNAMID national staff member, 4 May 2016. 
UNAMID Military/Police were informed and the information was circulated to their neighbouring counterparts. The driver and passenger were later released $3 \mathrm{kms}$ from Zalingeri. ${ }^{109}$

As well as theft, the security incident $\log$ references to $4 \mathrm{x} 4 \mathrm{~s}$ reveal a picture of a complex conflict involving surveillance and probing, military movements, collaboration between the United Nations, rebels and the Government of Sudan, tensions between the UN and Government of Sudan forces, and the importance of fuel,

On 18 January 2009 at Um Kadada four unidentified vehicles drove toward the UNAMID base from the south. Personnel on duty fired warning shots at the vehicles when they did not stop. After the shots were fired the vehicles turned off their lights and remained stationary for 15 minutes. When they began moving toward the camp again another warning shot was fired by the duty personnel before the vehicles drove away into the night. The security readiness state was increased in the camp and the sentries reinforced. GoS forces denied any knowledge of the incident when contacted by UNAMID staff.

On 19 April 2008 at about 09:30 hrs, convoy of eight (8) military Land Cruisers with eighty (80) personnel on board, believed to be loyal to [name of prominent Darfurian removed] arrived in Zalingie town on their way to Zalingie Military Camp. No motive of this movement has been established.

On 19 April, one (1) Land Cruiser belonging to the United Nations Human Rights (UNHR) was carjacked at $21 \mathrm{~h} 00$ while the driver was parking at her residence in El Fasher. Unconfirmed information suggests that the vehicle has been traced and arrangement made to recover. On 20 April, the vehicle was handed over by SLA/MM to UNAMID.

On 22 April 2008 at about 14:30 hrs, a vehicle of UN HR International staff member was blocked in the Zalingie market area. The UNDSS team informed the GoS Police, proceeded together to the scene and found a staff member being blocked back and front by NS, Police and Military vehicles. While other police and military personnel surrounding the area were with drawn guns. UNDS tried to neutralize the situation and advising the NS and Police to take the matter to NS Office and be discussed and to avoid the large crowd and armed soldiers who were mobilizing to the location of the incident.

On the 11 March 08, a UN Convoy going from El Fasher to Malagat (23 km NW of Kutum) was stopped by a armed Group at Hashaba-Um Lewa area and were asked for fuel. The team leader refused to hand over the fuel. The armed group forcibly removed the fuel. Then the Convoy was released and precede further to Tabaldia.

In these reports (and there are many hundreds like them), $4 \times 4$ s have functional roles in warfare - as troop carriers, a means to cart looted goods, or a way to conduct surveillance and test UN readiness. They shape the character of the violent conflict, allowing actors (government, pro-government militia, and rebels) to project their forces over long distances, across difficult territory, making looting and hit-and-run tactics feasible. They allow for the operation of semi-autonomous small groups of fighters (perhaps five or six vehicles operating under one commander) and thus do much to explain the fragmented nature of armed groups, and the consequent difficulties of achieving united negotiating positions among the rebel groups. ${ }^{110}$

109 All quotations are verbatim from the security incident log.

${ }^{110}$ Interview with former UNAMID national staff member, 4 May 2016. 
The $4 \times 4$ also shapes the conflict that is seen by the United Nations. The UN security incident log can only record incidents that are seen by UN peacekeepers, or incidents that are brought to the attention of the UN. While $4 \times 4 s$ are all terrain vehicles, they are limited in where they can go and therefore there are limits to the conflict that the UN can record - a factor that has implications for the policy responses to that conflict. Darfur is a vast area (over twice the size of the United Kingdom) and while UNAMID was authorised to have 19,555 uniformed personnel, the number provided was often under 10,000. ${ }^{111}$ Darfur is estimated to have a mere 2,000 km of roads (of all types, including roads that are planned but not yet completed). ${ }^{112}$ By comparison, the United Kingdom has $24,560 \mathrm{~km}$. As a result much of the territory was not visible to the UN. Moreover, given carjacking and attacks on vehicles and personnel, at various times the UN placed restrictions on when and where vehicles could be used, and on the minimum number of vehicles per assignment. ${ }^{113}$ As one UN official noted, 'The UN stick to safe places so fewer vehicles are stolen. ${ }^{, 14}$ A further factor limiting the extent to which UN personnel could monitor the ongoing conflict in Darfur took the form of restrictions, harassment, and foot-dragging from the Government of Sudan who, for example, often controlled access to sites of alleged incidents.

The chief point of this section is to highlight how the $4 \times 4$ (alongside other objects) shaped the conflict and thus how data on $4 \times 4$ s or perhaps other material objects can be used as a conflict analysis tool. Multiple conflict analysis models exist in the practitioner and policy worlds. Many of these are sophisticated and conflict sensitive. Yet they still face the problem of access to the conflict area due to violence, logistics, aggressive gatekeeping and the ethics of endangering the researched and the researcher. In the face of such obstacles, a case can be made for remote research that seeks to employ multiple methodologies in the hope that they can convey an accurate picture of conflict modalities. The advantage of examining the $4 \times 4$ data is that it provides information on conflict scale, geographies, patterns, resourcing, and consumption. Remote research, like remote management in humanitarianism, is not without its drawbacks and is recommended here in the absence of safe alternatives and is only viable because a peacekeeping operation is in situ and able to collect data. Yet the notion of following 'things' is worthy of further investigation in relation to conflict analysis. The advantage of a political economy of objects is that some objects tend to be in high volume circulation and have the capacity to provide an evidential trail. Crucially, these objects, whether the AK47, the Zippo lighter, ${ }^{115}$ or the mobile phone, can tell a story of actual usage - rather than of projected capability.

\section{Concluding discussion}

The principal aim of this article has been to assess what the study of material objects can bring to the analysis of conflict and intervention. The article has much sympathy with the new materialism literature, though given the case study origins of the article, it struggles to go along with all of the

111 Security Council Report, 'March 2008 Monthly Forecast: Darfur/Sudan, Security Council Report' (2008), available at: \{http://www.securitycouncilreport.org/monthly-forecast/2008-03/lookup_c_glKWLeMTIsG_b_ 3909133.php?print=true\} last accessed 8 August 2016.

112 Abdulla Bashir Hassan, 'Transportation infrastructure', in Hamid Eltgani Ali (ed.), Darfur's Political Economy: A Quest for Development (Abingdon: Routledge, 2014), pp. 243-65 (p. 250).

113 UN Joint Logistics Centre, 'Sudan Logistics Bulletin 84' (January 2007), available at: \{http://www.logcluster. org/sites/default/files/attachments/unjlc_sdn_monthly-bulletin_84_january_pub_070131.pdf\} last accessed 8 August 2016.

114 Interview with UN employee, UN Headquarters, New York, 23 May 2016.

115 Walters, 'Vietnam Zippos'. 
enthusiasms of the new materialism literature. As a result, the article proposes materialism+, a notion heavily influenced by new materialism and grateful to it for opening a window into the ontology and life-making power of objects.

A danger of concentrating on material objects is that we move towards posthumanism whereby people are removed from our analyses. It is tautological, but worth emphasising, that humanitarianism must involve a human (according to many a humane) dimension. ${ }^{116}$ Similarly, people-focused forms of conflict transformation are widely regarded as superior to shallower institutionalised forms of conflict resolution and conflict management. ${ }^{117}$ Although the current article has made clear that objects are agential and lead us to unpack the human/non-human divide, the very act of concentrating on material objects can lead to criticism that analytical space given to objects detracts from space given to humans, their agency and issues. Such a zero sum perspective would, however, miss the point of this article. The value of the posthuman lens lie primarily in the ontological and epistemological calculus that it encourages among researchers. Whether this is the dystopian view of posthuman soldiery ('horrific posthuman soldiers, genetically engineered and cyborged for obedience, conscienceless, fearlessness' $)^{118}$ or more optimistic views of humans enhanced by technology, ${ }^{119}$ posthumanism's promise lies in its challenge. In keeping with the new materialism literature, it forces us to think of its novelty (or lack thereof $\left.{ }^{120}\right)$, assemblages ${ }^{121}$ and context, and the motivations of those behind efforts to humanise, dehumanise, and rehumanise human subjects. ${ }^{122}$ A particularly important contribution of recent additions to the posthumanism literature has been a reminder of the importance of power, actual and discursive. As Anette-Carina van der Zaag notes, 'processes of power [are] constitutive of who gets to count as human in human/nonhuman relations'. ${ }^{123}$ Crucial here, and very pertinent when discussing material objects, is how advanced capitalism blurs the boundaries between people and things in an 'all-consuming commodification of life'. ${ }^{124}$

Indeed, the focus on $4 \times 4 \mathrm{~s}$, it can be argued, privileges well-resourced groups to the detriment of others. In Darfur, for example, not everyone has a $4 \times 4$ - it is a material privilege afforded to rebel, militia, and international elites. By choosing to examine the $4 \times 4$, the researcher is immediately drawn to gathering data on the topic - most obviously the security incident dataset from Darfur, but also facts and figures held by the UN and INGOs. The risk is that the material turn encourages a path dependency on particular types of data that have been gathered using specific technocratic methods. The danger is that we become prone to data fundamentalism whereby researchers examine

${ }^{116}$ Hugo Slim, 'Wonderful work: Globalising the ethics of humanitarian action', in Mac Ginty and Peterson (eds), The Routledge Companion to Humanitarian Action, pp. 13-25.

${ }^{117}$ Oliver Ramsbotham, Tom Woodhouse, and Hugh Miall, Contemporary Conflict Resolution (4th edn, Cambridge: Polity, 2015), pp. 10-11.

${ }^{118}$ Charles Hables Grey, 'Posthuman soldiers in postmodern war', Body and Society, 9:4 (2003), pp. 215-26 (pp. 224-5).

119 David Roden, Posthuman Life: Philosophy at the Edge of the Human (New York: Routledge 2015); Heidi A. Campbell, 'Framing the human-technology relationship: How religious digital creative engage posthuman narratives', Social Compass, 63:3 (2016), pp. 302-18.

${ }^{120}$ Erika Cudworth and Steve Hobden, 'The posthuman way of war', Security Dialogue, 46:6 (2015), pp. 513-29 (p. 524).

${ }^{121}$ Jason Dittmer, 'Geopolitical assemblages and complexity', Progress in Human Geography, 38:3 (2014), pp. 385-401 (p. 387).

${ }^{122}$ Squire, 'Desert "trash"'.

${ }^{123}$ Annette-Carina van der Zaag, 'On posthuman subjectivity', Journal of Cultural Economy, 9:3 (2016), pp. 330-6 (p. 330).

124 Ibid., p. 332. 
quantifiable and easily observable phenomena and overlook power, including structural power. Moreover, there is the risk that a concentration on material objects fuels a possible retreat from fieldwork, whereby researchers and increasingly risk averse institutions recommend desk-based or less exposed forms of field research.

It is hoped, however, that the discussion in this article has made clear the intersections between people and machines, and how vehicles and their usage are nested within wider power structures. The $4 \times 4$ on its own tells us little. Instead, any material turn in International Relations is best seen as a complementary methodological tool, able to augment but not substitute other approaches that are cognisant of structure, power, and agency. Examining $4 \times 4 s$ and their usage in humanitarian and conflict settings allows us to connect with debates on political economy, the sociology of conflict and intervention, and the hybrid nature of conflict and agency. It shows how different actors have been able to eke out, define and appropriate space. What becomes clear is that the space appropriated through $4 \times 4$ usage defies simple labels such a humanitarian, battle, or peace. Instead, spaces fashioned by $4 \times 4$ s are often complex, contested, and transitional. As well as the agency of the drivers, mechanics and passengers, they remind us of the structural power that enables some actors to project their presence in apparently 'remote' spaces. In order for a government, UN, INGO or rebel 4x4 to operate on a dirt road in Darfur there needs to be set of economies and enabling conditions in place, many of which are far removed from the physicality of the object. Apparently localised conflict and violence are globally constituted. ${ }^{125}$ The end-user is only one actor in an intricate process of interactionism. Such an observation is congruent with analyses that examine conflict and peacemaking as processes rather than events, and thus are alert to the structural, gendered, and economic aspects of conflict and violence. Crucially, and the subject for another article, the $4 \times 4$ points to a long chain of implication whereby apparently far away conflicts are connected to daily life in the global north through the use of very similar objects, manufactured in the same factories, and dependent on the same supply chains.

\section{Acknowledgements}

Thanks are due to the Economic and Social Research Council for funding the 'Making Peacekeeping Data Work for the International Community' project (ES/L007479/1). The following gave helpful comments on a draft of the article - Séverine Autesserre, Mark Duffield, Allard Duursma, Nemanja Džuverović, Pamina Firchow, Charles Hunt, and Róisín Read - apologies if I was too obtuse to follow their advice.

\section{Biographical information}

Roger Mac Ginty is Professor of Peace and Conflict Studies at the Humanitarian and Conflict Response Institute, and the Department of Politics at the University of Manchester. He edits the journal Peacebuilding (with Oliver Richmond) and works on local and bottom-up responses to international intervention.

125 Alison J. Ayers, 'Sudan's uncivil war: the global-historical constitution of political violence', Review of African Political Economy, 37:124 (2010), pp. 153-71 (p. 154); Gunnar M. Sørbø, 'Local violence and international intervention in Sudan', Review of African Political Economy, 37:124 (2010), pp. $173-86$. 